\title{
Tubular Epithelial Cell Count
}

National Cancer Institute

\section{Source}

National Cancer Institute. Tubular Epithelial Cell Count. NCI Thesaurus. Code C74775.

The determination of the number of tubular epithelial cells present in a urine sample. 